\title{
Identification of hub genes and molecular mechanisms in infant acute lymphoblastic leukemia with MLL gene rearrangement
}

\author{
Hao Zhang Equal first author, 1 , Juan Cheng ${ }^{\text {Equal first author, } 1}$, Zijian Li ${ }^{1}$, Yaming Xi ${ }^{\text {Corresp. } 1}$ \\ ${ }^{1}$ Department of hematology, The First Hospital of Lanzhou University, Lanzhou, Gansu, China \\ Corresponding Author: Yaming Xi \\ Email address: Idyyxyk@gmail.com
}

Infant acute lymphoblastic leukemia (ALL) with the mixed lineage leukemia $(M L L)$ gene rearrangement $(M L L-R)$ is considered a distinct leukemia from childhood or non-MLL-R infant ALL. To detect key genes and elucidate the molecular mechanisms of MLL-R infant $A L L$, microarray expression data were downloaded from the Gene Expression Omnibus (GEO) database, and differentially expressed genes (DEGs) between MLL-R and non-MLL-R infant ALL were identified. Gene ontology (GO) and Kyoto Encyclopedia of Genes and Genomes (KEGG) pathway enrichment analyses were carried out. Then, we constructed a protein-protein interaction (PPI) network and identified the hub genes. Finally, drug-gene interactions were mined. 139 cases of $M L L-R$ infant ALL including 77 (55.4\%) fusions with AF4, 38 (27.3\%) with ENL, 14 (10.1\%) with AF9, and 10 (7.2\%) other gene fusions were characterized. 236 up-regulated and 84 down-regulated DEGs were identified. The upregulated DEGs were mainly involved in homophilic cell adhesion, negative regulation of apoptotic process and cellular response to drug GO terms, while down-regulated DEGs were mainly enriched in extracellular matrix organization, protein kinase $\mathrm{C}$ signaling and neuron projection extension GO terms. The up-regulated DEGs were enriched in 7 KEGG pathways, mainly involving transcriptional regulation and signaling pathways, and downregulated DEGs were involved in 3 main KEGG pathways including alzheimer's disease, TGF-beta signaling pathway, and hematopoietic cell lineage. The PPI network included 297 nodes and 410 edges, with MYC, ALB, CD44, PTPRC and TNF identified as hub genes. 23 drug-gene interactions including 4 up-regulated hub genes and 24 drugs were constructed by Drug Gene Interaction database (DGIdb). In conclusion, MYC, ALB, CD44, PTPRC and TNF may be potential bio-markers for the diagnosis and therapy of MLL-R infant ALL. 


\section{Identification of hub genes and molecular}

\section{2 mechanisms in infant acute lymphoblastic leukemia \\ 3 with $M L L$ gene rearrangement}

Hao Zhang*, Juan Cheng*, Zijian Li, YaMing Xi

6

7 Department of hematology, The First Hospital of Lanzhou University, Lanzhou, Gansu, China

*Hao Zhang and Juan Cheng contributed equally to this work

Corresponding Author:

YaMing Xi

Email address: 1dyyxyk@gmail.com

\section{ABSTRACT}

Infant acute lymphoblastic leukemia (ALL) with the mixed lineage leukemia $(M L L)$ gene rearrangement $(M L L-\mathrm{R})$ is considered a distinct leukemia from childhood or non- $M L L-\mathrm{R}$ infant ALL. To detect key genes and elucidate the molecular mechanisms of $M L L-\mathrm{R}$ infant ALL, microarray expression data were downloaded from the Gene Expression Omnibus (GEO) database, and differentially expressed genes (DEGs) between $M L L-\mathrm{R}$ and non-MLL-R infant ALL were identified. Gene ontology (GO) and Kyoto Encyclopedia of Genes and Genomes (KEGG) pathway enrichment analyses were carried out. Then, we constructed a protein-protein interaction (PPI) network and identified the hub genes. Finally, drug-gene interactions were mined. 139 cases of $M L L-\mathrm{R}$ infant ALL including 77 (55.4\%) fusions with $A F 4,38$ (27.3\%) with $E N L, 14(10.1 \%)$ with $A F 9$, and 10 (7.2\%) other gene fusions were characterized. 236 upregulated and 84 down-regulated DEGs were identified. The up-regulated DEGs were mainly involved in homophilic cell adhesion, negative regulation of apoptotic process and cellular response to drug GO terms, while down-regulated DEGs were mainly enriched in extracellular 
29

30

31

32

33

34

35

36

37

38

39

40

41

42

43

44

45

46

47

48

49

50

51

52

53

54

55

56

57

58

59

60

61

62

63

64

65

matrix organization, protein kinase $\mathrm{C}$ signaling and neuron projection extension $\mathrm{GO}$ terms. The up-regulated DEGs were enriched in 7 KEGG pathways, mainly involving transcriptional regulation and signaling pathways, and down-regulated DEGs were involved in 3 main KEGG pathways including alzheimer's disease, TGF-beta signaling pathway, and hematopoietic cell lineage. The PPI network included 297 nodes and 410 edges, with $M Y C, A L B, C D 44, P T P R C$ and $T N F$ identified as hub genes. 23 drug-gene interactions including 4 up-regulated hub genes and 24 drugs were constructed by Drug Gene Interaction database (DGIdb). In conclusion, $M Y C$, $A L B, C D 44, P T P R C$ and $T N F$ may be potential bio-markers for the diagnosis and therapy of $M L L-\mathrm{R}$ infant ALL.

\section{INTRODUCTION}

Infant acute lymphoblastic leukemia (ALL) refers to ALL arising in infants prior to 12 months of age. Infant ALL is less common but more aggressive than pediatric ALL, generally with a poorer outcome (Brown, Pieters \& Biondi, 2019; Pieters et al., 2007). Despite advances in the treatment of pediatric ALL, $>50 \%$ of patients with infant ALL relapse within five years of diagnosis, and the four-year event-free survival is $<50 \%$ (Hilden et al., 2006; Nagayama et al., 2006).

Approximately $80 \%$ of infant ALL cases are characterized genetically by rearrangements in the mixed lineage leukemia gene ( $M L L$, also known as $K M T 2 A$, located on chromosome 11q23) (Krivtsov \& Armstrong, 2007). These rearrangements occur in nearly $100 \%$ of infants with congenital leukemia and approximately $5 \%$ of pediatric ALL patients, with predicted inferior outcomes (van der Linden et al., 2009). Previous studies have shown that infant ALL with MLL rearrangements $(M L L-\mathrm{R})$ were clinically distinct, and were characterized by high white blood cell counts, hepatosplenomegaly, and central nervous system and skin involvement (Hilden et al., 2006). The 4-5-year event-free survival for $M L L-\mathrm{R}$ infant ALL patients was $29.1 \%-43.2 \%$, compared with $56.9 \%-95.5 \%$ for patients without $M L L$ rearrangements (non- $M L L-\mathrm{R})(\mathrm{Guest} \&$ Stam, 2017). Standard strategy for MLL-R infant ALL is intensive chemotherapy with or without hematopoietic stem cell transplantation (HSCT). Although allogeneic HSCT may contribute to improve the inferior prognosis of $M L L-\mathrm{R}$ infant ALL, it was restricted to some patients because of early relapse before HSCT (Tomizawa et al., 2007). Early (within 4 months of the first induction course) use of allogeneic HSCT could help to reduce the rate of early relapse, however, could not ovecome the high risk factors including younger than 90 days at diagnosis, central nervous system involvment and poor prednisone response (Koh et al., 2015). Recent studies evaluated the effect of several innovative approaches such as FLT3 inhibitors, epigenetic agents and immunotherapy in $M L L$-R infant ALL, the results were still far from satisfactory (Brown, Pieters \& Biondi, 2019). Thus novel treatment targets and molecular-targeted strategies are required to improve outcomes of infant ALL patients with $M L L-\mathrm{R}$. 
67 More than 90 different $M L L$ partner genes have been identified to date. Frequent $M L L$

68 rearrangements in infant ALL include fusions with $A F 4$ (49\%), ENL (22\%), AF9 (16\%), and

$69 A F 10(6 \%)$ (Meyer et al., 2018). All types of rearrangements in $M L L$ were independently

70 associated with an unfavorable prognosis (Pieters et al., 2007). Several studies found that $M L L$

71 rearrangements occurred in utero, resulting in rapid progression to leukemia (Brown et al., 2019;

72 Ford et al., 1993; Gale et al., 1997). Notably, this phenomenon showed a high concordance rate

73 between identical twins (Greaves et al., 2003; Guest \& Stam, 2017). These findings revealed that

$74 M L L$ rearrangements may initiate leukemogenesis for $M L L-\mathrm{R}$ infant ALL. However, $M L L-A F 4$

75

76

77

78

79

80

81

82

83

84

85

86

87

88

89

90

91

92

93

94

95

96

97 98 expression alone was not sufficient to induce leukemia in human embryonic stem cell-derived hematopoietic cells, and additional genetic candidates were required (Stam, 2013). These results suggested that the mechanisms responsible for $M L L-\mathrm{R}$ infant ALL are distinct from those acting during leukemogenesis in childhood and non-MLL-R infant ALL.

We investigated the molecular mechanisms of $M L L-\mathrm{R}$ infant ALL by determining differentially expressed genes (DEGs) between $M L L-\mathrm{R}$ and non- $M L L-\mathrm{R}$ infant ALL, using available microarray datasets, followed by bio-functional enrichment of identified DEGs. These results will provide new insights into the molecular mechanisms behind ALL in infants with MLL rearrangements, and help identify new diagnostic bio-markers and candidate therapeutic targets.

\section{MATERIALS \& METHODS}

\section{Microarray data collection}

Microarray expression data in the Gene Expression Omnibus (GEO) database (http://www.ncbi.nlm.nih.gov/geo) (Barrett et al., 2013), ArrayExpress database (https://www.ebi.ac.uk/arrayexpress/) and The Cancer Genome Atlas (TCGA) database (https://cancergenome.nih.gov/), were searched using the keywords "acute lymphoblastic leukemia", and data containing expression profiles of $M L L-\mathrm{R}$ compared with non-MLL-R infant ALL cases were selected manually. Raw CEL files were downloaded for further analysis.

Identification of DEGs

Gene expression profile data were preprocessed using the robust multi-array average (RMA) algorithm by Affy package in R (version 1.58.0) (Gautier et al., 2004), including background 
adjustment, normalization, and summarization. According to annotation files, the mean value was computed for several probes matched to a specific gene, and used as the expression value of that gene. DEGs between $M L L-\mathrm{R}$ and non- $M L L-\mathrm{R}$ infant ALL cases were identified using the Bayesian method by Limma package in R (version 3.36.5) (Ritchie et al., 2015). | $\log 2$ fold change (FC) $\mid>1(\log 2 \mathrm{FC}>1$ defined as upregulated genes, $\log 2 \mathrm{FC}<-1$ defined as downregulated genes) and a $\mathrm{P}$ value $<0.01$ were considered as threshold points.

\section{Gene functional enrichment analysis}

Gene ontology (GO) functional annotation analyses including biological processes (BP), cellular components (CC), molecular function (MF) terms and Kyoto Encyclopedia of Genes and Genomes (KEGG) pathway analysis were performed using the Database for Annotation, Visualization and Integrated Discovery (DAVID) v6.8 (Huang da, Sherman \& Lempicki, 2009), with a default cut-off criterion of count $\geq 2$ and $\mathrm{P}$ value $<0.1$.

\section{Protein-protein interaction network construction and analysis}

A protein-protein interaction (PPI) network of DEGs was constructed using the STRING (version 10.5, http://www.string-db.org/) database (von Mering et al., 2003), with minimum required interaction score $>0.4$ (median confidence). The PPI network was visualized using Cytoscape (version 3.7.1, http://www.cytoscape.org/) (Shannon et al., 2003). Bio-functional modules in the PPI network were explored using a plug-in MCODE (version 1.4.2, http://apps.cytoscape.org/apps/MCODE) in Cytoscape with Node Score Cutoff of 0.2 and KCore of 2. Hub genes were screened using the plug-in CytoHubba (version 2.1.6, http://apps.cytoscape.org/apps/cytohubba) in Cytoscape with methods including maximal clique centrality, degree, and betweenness.

\section{Drug-gene interactions analyses}

Drug-gene interactions were searched from the Drug-Gene Interaction database (DGIdb, v3.0.2, http://www.dgidb.org/) (Cotto et al., 2018), which mines known or predicted interactions from existing databases and literature, using the list of hub genes. The preset filter was setted to antineoplastic which was defined by the inclusion of anti-neoplastic drug-gene interaction source databases (e.g. My Cancer Genome, PharmGKB, DrugBank), while advanced filters were setted to 20 source databases, 41 gene categories and 51 interaction types. The interactions were visualized using Cytoscape. 


\section{RESULTS}

134

135 Microarray datasets and patient characteristics

136 Based on searches in the GEO, ArrayExpress and TCGA databases, two microarray datasets,

137 GSE68720 and GSE19475, that met the criteria mentioned in methods section, were selected for 138 analysis. Both datasets were generated using the GPL570 Affymetrix Human Genome U133 Plus 1392.0 Array platform. There were $80 M L L-\mathrm{R}$ and 17 non-MLL-R infant ALL samples in the 140 GSE68720 dataset, and 59 and 14, respectively, in the GSE19475 dataset. The age range of the $141139 \mathrm{MLL}$-R infant ALL cases (65 male, 73 female and 1 unknown) was 0-363 days, and the age 142 range of the 31 non- $M L L-\mathrm{R}$ infant ALL cases (22 male, 9 female) was 0-365 days. $M L L-\mathrm{R}$ infant 143 ALL displayed 77 (55.4\%) AF4, 38 (27.3\%) ENL, 14 (10.1\%) AF9, and 10 (7.2\%) other gene 144 fusions.

145

\section{Identification of DEGs}

147 To probe significant alterations of gene expression profile related to $M L L-\mathrm{R}$, differential expression analysis of genes was performed using Limma package. Based on the cut-off criteria, a total of 320 DEGs, including 236 up-regulated and 84 down-regulated genes, were identified between $M L L-\mathrm{R}$ and non- $M L L-\mathrm{R}$ infant ALL samples. The top five up-regulated DEGs were $L A M P 5, P R O M 1, C C N A 1, M E I S 1$, and $K C N K 12$, and the top five down-regulated DEGs were $M M E, C M T M 8, E L K 3, N R N 1$, and PLEKHG4B (Fig. 1).

153

\section{GO functional annotation and KEGG pathway analyses}

155

156

157

158

159

160

161

162

163

164
To identify the biologic functions of DEGs, GO functional annotation and KEGG pathway analyses were carried out. The results showed that up-regulated DEGs were enriched in $62 \mathrm{BP}$, $21 \mathrm{CC}$, and $22 \mathrm{MF}$ terms, and down-regulated DEGs were enriched in $34 \mathrm{BP}, 22 \mathrm{CC}$, and $17 \mathrm{MF}$ terms. The top five significant terms are shown in Fig. 2, Fig. 3 and Fig. 4. The up-regulated DEGs were also enriched in seven KEGG pathways, mainly involving transcriptional regulation and signaling pathways, and down-regulated DEGs were enriched in three KEGG pathways including alzheimer's disease, TGF-beta signaling pathway, and hematopoietic cell lineage (Table 1).

\section{PPI network construction and analysis}

Peer) reviewing PDF | (2019:04:36669:1:1:NEW 13 Jul 2019) 
165

166

167

168

169

170

171

172

173

174

175

176

177

178

179

180

181

182

183

184

185

186

187

188

189

190

191

192

193

194

195

196

197

198

199

200

The STRING online database and Cytoscape were used to detected interactions between DEGsencoded proteins by constructing PPI network. The PPI network of DEGs included 297 nodes and 410 edges (Fig. 5). Five bio-functional modules were screened out, based on the cut-off criteria, and the maximal MCODE score of module, which consisted of 15 nodes and 75 edges, was 10.714. This module contained 11 up-regulated (e.g. MYC, CD44, and PTPRC, etc.) and four down-regulated (e.g. TNF, $M M E$, and RAG1, etc.) DEGs (Fig. 6). The top 10 hub genes identified by Cytoscape, using maximal clique centrality, degree and betweenness, are listed in Table 2. MYC, $A L B, C D 44, P T P R C$ and TNF were identified as hub genes based on all three methods.

\section{Drug-gene interactions analyses}

To explore potentially drugs for patients with $M L L-\mathrm{R}$, the network of drug-gene interactions were constructed by DGIdb with 29783 drug-gene interactions consist of 41100 genes and 9495 drugs. As a result, 23 drug-gene interactions including 4 up-regulated hub genes $(M Y C, A L B$, $C D 44, P T P R C)$ and 24 drugs were identified, as shown in Fig. 7.

\section{DISCUSSION}

MLL, encoded by the histone-lysine N-methyltransferase 2A (KMT2A), is a transcriptional coactivator that binds with other proteins in complex and methylates histone H3 lysine 4 which acts as an instructive mark for transcription initiation (Mohan et al., 2010). Rearrangements of $M L L$ results in the fusion of its $\mathrm{N}$-terminus with the C-terminus of a partner gene, leading to transcription dysregulation (Armstrong, Golub \& Korsmeyer, 2003). Previous research identified more than 90 fusion genes of $M L L$, including the frequent $M L L$ rearrangement in infant ALL $\mathrm{t}(4 ; 11)(\mathrm{q} 21 ; \mathrm{q} 23)$, which results in the $M L L-A F 4$ fusion (Meyer et al., 2018; Meyer et al., 2013). In the present study, three partner genes accounted for $92.8 \%$ of 139 cases: $M L L-A F 4$ (55.4\%), $M L L-E N L(27.3 \%)$, and $M L L-A F 9$ (10.1\%). To confirm that the molecular mechanisms responsible for $M L L-\mathrm{R}$ infant ALL differs from those of childhood or non- $M L L-\mathrm{R}$, we analyzed differences in gene expression profiles between $M L L-\mathrm{R}$ and non-MLL-R infant ALL samples, based on microarray datasets obtained from the GEO database. Two microarray datasets were selected, and a total of 320 DEGs with fold-change $>2$ were screened out, including 236 upregulated genes (e.g. $L A M P 5, P R O M 1, C C N A 1, M E I S 1$, and KCNK12) and 84 down-regulated genes (e.g. PLEKHG4B, NRN1, ELK3, CMTM8, and MME). These results provide preliminary evidence for the distinct mechanisms of $M L L-\mathrm{R}$ infant ALL. We further investigated the functions of these DEGs and their possible roles in $M L L-\mathrm{R}$ infant ALL using DAVID functional annotations. In GO-BP, the top three significant terms were homophilic cell adhesion, negative 
201 regulation of apoptosis and cellular responses to drugs. Homophilic cell adhesion, mediated by

202 the up-regulation of protocadherin $(P C D H)$ y subfamily of genes (e.g. PCDHGA, $P C D H G B$,

$203 P C D H G C$ ) may contribute to cell migration and invasion. Previous studies have confirmed that

$204 P C D H$ genes were involved in tumorigenesis and metastasis of gastric cancer, follicular

205 lymphoma and non-small cell lung cancer (Mukai et al., 2017; Zhang et al., 2016; Zhou et al.,

206 2017), although other studies have found that $P C D H$ genes were implicated in tumor suppression

207 (Chen et al., 2017; Weng et al., 2018). However, the role of PCDH genes in $M L L-\mathrm{R}$ ALL is

208 currently unclear. SOCS2, one of the up-regulated DEGs enriched in negative regulation of

209 apoptosis, is demonstrated to be a feedback inhibitor of JAK-STAT signaling pathways. High

210 levels of SOCS2 was identified as an adverse prognostic characteristic of acute myeloid

211 leukemia (AML) and ALL, such as those with $M L L$ rearrangement or $B C R / A B L$ fusions (Hansen

212 et al., 2013; Vitali et al., 2015). MEF2C, RAP2A, PDE4A, PPP3CA, PRNP, and MYC were

213 enriched in the GO-BP term cellular responses to drugs which may be involved in

214 chemoresistance. As a transcription factor related to normal hematopoiesis, myocyte enhancer

215 factor 2C (MEF2C) was involved in a number of transcriptional complexes (Cante-Barrett,

216 Pieters \& Meijerink, 2014). $M E F 2 C$ was significantly up-regulated in acute leukemia with $M L L-$

217 R, while known as an adverse prognostic marker in AML (Laszlo et al., 2015). Recent research

218 suggested that $M E F 2 C$ was related to AML chemoresistance caused by the phosphorylation of

219 MEF2C S222 (Brown et al., 2018). PDE4A, encodes one of phosphodiesterases (PDEs), is

220 abundantly expressed in leukemia cell lines. Inhibitors of PDE4 augmented apoptosis induced by

221 glucocorticoid and overcame the resistance to glucocorticoid in leukemia cells (Dong et al., 2010;

222 Ogawa et al., 2002).

223

224

We further uncovered molecular mechanistic insights of $M L L-\mathrm{R}$ ALL by KEGG pathway

225 analysis, using the DAVID tool. The most significant pathway affected was transcriptional

226 misregulation in cancer, which was enriched with up-regulated DEGs, including $M E F 2 C$, PROM1, CEBPA, LMO2, FLT3, RUNX1, HMGA2, RUNX2, MEIS1, MYC, and WT1. Some of

228 these genes have been defined as $M L L$ targets genes. MEIS1, which is known as a key regulator

229 in transcriptional regulation, cellular differentiation, and cell-cycle control, exhibited significant

230 increases in both MLL fusion protein binding and mRNA expression on $M L L-E N L$ activation in

231

232 $M L L-E N L$ leukemia cases and in an inducible cellular model (Wang et al., 2011). Further

233 research also indicated that MEIS1 was essential for the development of $M L L$ leukemia, by promoting cell differentiation resistance, and it was also confirmed to be involved in chemotherapy resistance (Rosales-Avina et al., 2011). As a downstream gene, HMGA2 was positively regulated by MLL fusion proteins in infant $M L L-A F 4$ ALL leukemic cells (Wu et al., 2015). PROM1 is a commonly used stem cell and cancer stem cell marker, and $M L L-A F 4$ was shown to promote $P R O M 1$ transcription, which is required for $M L L-A F 4$-driven leukemia cell growth (Mak, Nixon \& Moffat, 2012). FLT3 is a class III receptor tyrosine kinase that plays an important role in hematopoietic stem cell development, high levels of FLT3 are a common 
240

241

242

243

244

245

246

247

248

249

250

251

252

253

254

255

256

257

258

259

260

261

262

263

264

265

266

267

268

269

270

271

272

273

274

275

276

277

cooperating event in MLL-AF4 ALL (Bueno et al., 2013). The presence of activating FLT3 mutations in $M L L$ is in keeping with a multistep pathway of leukemogenesis, suggesting that FLT3 mutations may act as a second hit to lead to leukemogenesis in $M L L-\mathrm{R}$ infants (Kang et al., 2012). LMO2 plays an important role in hematopoiesis and leukemogenesis, Begay-Muller's research indicated that AF6, a recurrent fusion partner of $M L L$, bound to $L M O 2$ and may be involved in mixed lineage leukemia (Begay-Muller, Ansieau \& Leutz, 2002). RUNX1 is known to be a putative target gene of $M L L$ fusions, and was highly expressed in $M L L-A F 4$ ALL cases, when compared with normal bone marrow cells (Guenther et al., 2008; Krivtsov et al., 2008). The BET inhibitor I-BET151, arrested the growth of $M L L-A F 4$ infant leukemic cells in vitro through gene deregulation, including RUNX1 (Bardini et al., 2018).

We examined interrelationships among the DEGs by constructing a PPI network using the STRING database and Cytoscape, and identified MYC, ALB, CD44, PTPRC and TNF as hub genes. $M Y C$ has been shown to be a direct target of $M L L-A F 9$ and is differentially expressed between neonatal and adult cells expressing $M L L-A F 9$ (Zuber et al., 2011). Notably, expression of the neonatal, but not the adult $M L L-A F 9$ signature, was also enriched in a core $M Y C$ network, suggesting that neonatal cells are inherently more prone to $M L L-A F 9$-mediated immortalization than adult cells (Horton et al., 2013). Furthermore, MYC was essential for MLL-ENL to promote differentiation arrest of myelomonocytic precursor cells, and constitutive MYC expression cooperated with $M L L-E N L$ to transform cells, with irreversible maturation arrest (Schreiner et al., 2001). CD44 is a type I transmembrane glycoprotein and a leukocyte marker expressed on hematopoietic cells, various epithelial cell types, fibroblasts, and endothelial cells. The current findings revealed that CD44 is a surface marker of cancer stem cells (Yan, Zuo \& Wei, 2015). $M L L-\mathrm{R}$ ALL had a unique genetic profile clearly distinguishable from those of other types of leukemia, with very high CD44 levels (Tsutsumi et al., 2003). Furthermore, CD44 expression represented the early steps of lymphoid development, high levels of CD44 were associated with maturation arrest at an early lymphoid progenitor stage of development, while levels decreased with maturation (Armstrong et al., 2002). PTPRC gene encodes for the protein tyrosine phosphatase $C D 45$, which acts as a haematopoietic $J A K$ phosphatase required for lymphocyte activation and development (Irie-Sasaki et al., 2001; Trowbridge \& Thomas, 1994). High levels of PTPRC (CD45) were associated with poor prednisone response followed by an inferior prognosis in B-cell-precursor ALL and T-cell ALL with $M L L-A F 4$ (Cario et al., 2014). However, the roles of ALB up-regulation and TNF down-regulation in $M L L-\mathrm{R}$ ALL remain unclear. Besides, it should be noted that NG2 was widely known as a marker and therapeutic target for MLL-R leukemia (Behm et al., 1996; Hilden et al., 1997; Lopez-Millan et al., 2019; Smith et al., 1996; Wuchter et al., 2000), but it was not be identified as hub gene in this study may be caused by the special threshold used for the computational analyses.

PeerJ reviewing PDF | (2019:04:36669:1:1:NEW 13 Jul 2019) 
278 In addition, 24 antineoplastic drugs were forecasted based on up-regulated hub genes. Some of 279 these drugs have been used in the treatment of acute leukemia (Chijimatsu et al., 2017; Mosse et 280 al., 2019; Schultz et al., 2014; Teuffel et al., 2011). The rest of them could be potential treatment 281 options for infant $M L L-\mathrm{R}$ ALL.

282

283 Nevertheless, it should be noted that the results of this research were obtained by bioinformatics 284 analysis, further experimental and clinical validation should be the focus of our future research.

285

286

CONCLUSIONS

287

288

In this study, bioinformatics analyses were performed to detected novel candidate biomarkers

289 and uncover possible molecular mechanisms of $M L L-\mathrm{R}$ infant ALL. The results indicated that

290 the hub genes $M Y C, A L B, C D 44, P T P R C$ and $T N F$, together with some biological events

291 including negative regulation of apoptotic processes, monocyte differentiation, homophilic cell

292 adhesion, and transcriptional misregulation, may contributed to leukemogenesis, migration, and

293 invasion in $M L L-\mathrm{R}$ infant ALL. And several drugs were predicted based on the hub genes. All

294 these findings provide novel biomarkers and potential therapeutic approaches for $M L L-\mathrm{R}$ infant 295 ALL.

296

297

ACKNOWLEDGMENTS

298

299

The authors would like to acknowledge the Gene Expression Omnibus database for providing 300 raw data in this study.

301

302

REFERENCES

303

304

Armstrong SA, Golub TR, Korsmeyer SJ. 2003. MLL-rearranged leukemias: insights from gene 305 expression profiling. Seminars in Hematology 40:268-273.

306 
307 Armstrong SA, Staunton JE, Silverman LB, Pieters R, den Boer ML, Minden MD, Sallan SE, 308 Lander ES, Golub TR, Korsmeyer SJ. 2002. MLL translocations specify a distinct gene 309 expression profile that distinguishes a unique leukemia. Nature Genetics 30:41-47 DOI $310 \quad 10.1038 / \mathrm{ng} 765$.

311

312 Bardini M, Trentin L, Rizzo F, Vieri M, Savino AM, Garrido Castro P, Fazio G, Van Roon EHJ, 313 Kerstjens M, Smithers N, Prinjha RK, Te Kronnie G, Basso G, Stam RW, Pieters R, Biondi A, 314 Cazzaniga G. 2018. Antileukemic Efficacy of BET Inhibitor in a Preclinical Mouse Model of 315 MLL-AF4(+) Infant ALL. Molecular Cancer Therapeutics 17:1705-1716 DOI 10.1158/1535316 7163.MCT-17-1123.

317

318

319

320

321

322

323

324

325

326

Barrett T, Wilhite SE, Ledoux P, Evangelista C, Kim IF, Tomashevsky M, Marshall KA, Phillippy KH, Sherman PM, Holko M, Yefanov A, Lee H, Zhang N, Robertson CL, Serova N, Davis S, Soboleva A. 2013. NCBI GEO: archive for functional genomics data sets--update. Nucleic Acids Research 41:D991-995 DOI 10.1093/nar/gks1193.

Begay-Muller V, Ansieau S, Leutz A. 2002. The LIM domain protein Lmo2 binds to AF6, a translocation partner of the MLL oncogene. FEBS Letters 521:36-38.

Behm FG, Smith FO, Raimondi SC, Pui CH, Bernstein ID. 1996. Human homologue of the rat 327 chondroitin sulfate proteoglycan, NG2, detected by monoclonal antibody 7.1 , identifies

328 childhood acute lymphoblastic leukemias with $\mathrm{t}(4 ; 11)(\mathrm{q} 21 ; \mathrm{q} 23)$ or $\mathrm{t}(11 ; 19)(\mathrm{q} 23 ; \mathrm{p} 13)$ and MLL gene rearrangements. Blood 87:1134-1139.

330

331

Brown FC, Still E, Koche RP, Yim CY, Takao S, Cifani P, Reed C, Gunasekera S, Ficarro SB, 332 Romanienko P, Mark W, McCarthy C, de Stanchina E, Gonen M, Seshan V, Bhola P, O'Donnell C, Spitzer B, Stutzke C, Lavallee VP, Hebert J, Krivtsov AV, Melnick A, Paietta EM, Tallman MS, Letai A, Sauvageau G, Pouliot G, Levine R, Marto JA, Armstrong SA, Kentsis A. 2018. MEF2C Phosphorylation Is Required for Chemotherapy Resistance in Acute Myeloid Leukemia. Cancer Discovery 8:478-497 DOI 10.1158/2159-8290.CD-17-1271.

337

338

Brown P, Pieters R, Biondi A. 2019. How I treat infant leukemia. Blood 133:205-214 DOI

339 10.1182/blood-2018-04-785980.

340

Bueno C, Ayllon V, Montes R, Navarro-Montero O, Ramos-Mejia V, Real PJ, Romero-Moya D, 342 Arauzo-Bravo MJ, Menendez P. 2013. FLT3 activation cooperates with MLL-AF4 fusion protein to abrogate the hematopoietic specification of human ESCs. Blood 121:3867-3878, S3861-3863 DOI 10.1182/blood-2012-11-470146. 
346 Cante-Barrett K, Pieters R, Meijerink JP. 2014. Myocyte enhancer factor 2C in hematopoiesis

347 and leukemia. Oncogene 33:403-410 DOI 10.1038/onc.2013.56.

348

349 Cario G, Rhein P, Mitlohner R, Zimmermann M, Bandapalli OR, Romey R, Moericke A,

350 Ludwig WD, Ratei R, Muckenthaler MU, Kulozik AE, Schrappe M, Stanulla M, Karawajew L.

351 2014. High CD45 surface expression determines relapse risk in children with precursor B-cell

352 and T-cell acute lymphoblastic leukemia treated according to the ALL-BFM 2000 protocol.

353 Haematologica 99:103-110 DOI 10.3324/haematol.2013.090225.

354

355

Chen HF, Ma RR, He JY, Zhang H, Liu XL, Guo XY, Gao P. 2017. Protocadherin 7 inhibits cell

356

357 migration and invasion through E-cadherin in gastric cancer. Tumor Biology

358

359 39:1010428317697551 DOI 10.1177/1010428317697551.

360

Chijimatsu I, Imanaka Y, Tomizawa D, Eguchi M, Nishimura S, Karakawa S, Miki M,

361 Hamamoto K, Fujita N. 2017. Azacitidine successfully maintained the second remission in an infant with KMT2A-rearranged acute lymphoblastic leukemia who relapsed after unrelated cord

362 blood transplantation. Pediatric Blood \& Cancer 64 DOI 10.1002/pbc.26697.

363

364

Cotto KC, Wagner AH, Feng YY, Kiwala S, Coffman AC, Spies G, Wollam A, Spies NC,

365 Griffith OL, Griffith M. 2018. DGIdb 3.0: a redesign and expansion of the drug-gene interaction 366 database. Nucleic Acids Research 46:D1068-D1073 DOI 10.1093/nar/gkx1143.

367

368

Dong H, Zitt C, Auriga C, Hatzelmann A, Epstein PM. 2010. Inhibition of PDE3, PDE4 and 369 PDE7 potentiates glucocorticoid-induced apoptosis and overcomes glucocorticoid resistance in

370 CEM T leukemic cells. Biochemical Pharmacology 79:321-329 DOI 10.1016/j.bcp.2009.09.001.

371

372

Ford AM, Ridge SA, Cabrera ME, Mahmoud H, Steel CM, Chan LC, Greaves M. 1993. In utero

373 rearrangements in the trithorax-related oncogene in infant leukaemias. Nature 363:358-360 DOI

374 $10.1038 / 363358 \mathrm{a} 0$.

375

376

Gale KB, Ford AM, Repp R, Borkhardt A, Keller C, Eden OB, Greaves MF. 1997. Backtracking

377 leukemia to birth: identification of clonotypic gene fusion sequences in neonatal blood spots.

378 Proceedings of the National Academy of Sciences of the United States of America 94:13950-

379 13954.

380

381

Gautier L, Cope L, Bolstad BM, Irizarry RA. 2004. affy--analysis of Affymetrix GeneChip data 382 383 at the probe level. Bioinformatics 20:307-315 DOI 10.1093/bioinformatics/btg405. history. Blood 102:2321-2333 DOI 10.1182/blood-2002-12-3817. 
386

387

388

389

390

391

392

393

394

395

396

397

398

399

400

401

402

403

404

405

406

407

408

409

410

411

412

413

414

415

416

417

418

419

420

421

422

423

424

425
Guenther MG, Lawton LN, Rozovskaia T, Frampton GM, Levine SS, Volkert TL, Croce CM, Nakamura T, Canaani E, Young RA. 2008. Aberrant chromatin at genes encoding stem cell regulators in human mixed-lineage leukemia. Genes \& Development 22:3403-3408 DOI $10.1101 / \operatorname{gad} .1741408$.

Guest EM, Stam RW. 2017. Updates in the biology and therapy for infant acute lymphoblastic leukemia. Current Opinion in Pediatrics 29:20-26 DOI 10.1097/MOP.0000000000000437.

Hansen N, Agerstam H, Wahlestedt M, Landberg N, Askmyr M, Ehinger M, Rissler M, Lilljebjorn H, Johnels P, Ishiko J, Melo JV, Alexander WS, Bryder D, Jaras M, Fioretos T. 2013. SOCS2 is dispensable for BCR/ABL1-induced chronic myeloid leukemia-like disease and for normal hematopoietic stem cell function. Leukemia 27:130-135 DOI 10.1038/leu.2012.169.

Hilden JM, Dinndorf PA, Meerbaum SO, Sather H, Villaluna D, Heerema NA, McGlennen R, Smith FO, Woods WG, Salzer WL, Johnstone HS, Dreyer Z, Reaman GH, Children's Oncology G. 2006. Analysis of prognostic factors of acute lymphoblastic leukemia in infants: report on CCG 1953 from the Children's Oncology Group. Blood 108:441-451 DOI 10.1182/blood-200507-3011.

Hilden JM, Smith FO, Frestedt JL, McGlennen R, Howells WB, Sorensen PH, Arthur DC, Woods WG, Buckley J, Bernstein ID, Kersey JH. 1997. MLL gene rearrangement, cytogenetic 11q23 abnormalities, and expression of the NG2 molecule in infant acute myeloid leukemia. Blood 89:3801-3805.

Horton SJ, Jaques J, Woolthuis C, van Dijk J, Mesuraca M, Huls G, Morrone G, Vellenga E, Schuringa JJ. 2013. MLL-AF9-mediated immortalization of human hematopoietic cells along different lineages changes during ontogeny. Leukemia 27:1116-1126 DOI 10.1038/leu.2012.343.

Huang da W, Sherman BT, Lempicki RA. 2009. Systematic and integrative analysis of large gene lists using DAVID bioinformatics resources. Nature Protocols 4:44-57 DOI 10.1038/nprot.2008.211.

Irie-Sasaki J, Sasaki T, Matsumoto W, Opavsky A, Cheng M, Welstead G, Griffiths E, Krawczyk C, Richardson CD, Aitken K, Iscove N, Koretzky G, Johnson P, Liu P, Rothstein DM, Penninger JM. 2001. CD45 is a JAK phosphatase and negatively regulates cytokine receptor signalling. Nature 409:349-354 DOI 10.1038/35053086.

Kang H, Wilson CS, Harvey RC, Chen IM, Murphy MH, Atlas SR, Bedrick EJ, Devidas M, Carroll AJ, Robinson BW, Stam RW, Valsecchi MG, Pieters R, Heerema NA, Hilden JM, Felix 
426 CA, Reaman GH, Camitta B, Winick N, Carroll WL, Dreyer ZE, Hunger SP, Willman CL. 2012. 427 Gene expression profiles predictive of outcome and age in infant acute lymphoblastic leukemia: 428 a Children's Oncology Group study. Blood 119:1872-1881 DOI 10.1182/blood-2011-10-382861.

429

430

431

432

433

434

435

436

437

438

439

440

441

442

443

444

445

446

447

448

449

450

451

452

453

454

455

456

457

458

459

460

461

462

463

464

465

Koh K, Tomizawa D, Moriya Saito A, Watanabe T, Miyamura T, Hirayama M, Takahashi Y, Ogawa A, Kato K, Sugita K, Sato T, Deguchi T, Hayashi Y, Takita J, Takeshita Y, Tsurusawa M, Horibe K, Mizutani S, Ishii E. 2015. Early use of allogeneic hematopoietic stem cell transplantation for infants with MLL gene-rearrangement-positive acute lymphoblastic leukemia. Leukemia 29:290-296 DOI 10.1038/leu.2014.172.

Krivtsov AV, Armstrong SA. 2007. MLL translocations, histone modifications and leukaemia stem-cell development. Nature Reviews Cancer 7:823-833 DOI 10.1038/nrc2253.

Krivtsov AV, Feng Z, Lemieux ME, Faber J, Vempati S, Sinha AU, Xia X, Jesneck J, Bracken AP, Silverman LB, Kutok JL, Kung AL, Armstrong SA. 2008. H3K79 methylation profiles define murine and human MLL-AF4 leukemias. Cancer Cell 14:355-368 DOI 10.1016/j.ccr.2008.10.001.

Laszlo GS, Alonzo TA, Gudgeon CJ, Harrington KH, Kentsis A, Gerbing RB, Wang YC, Ries RE, Raimondi SC, Hirsch BA, Gamis AS, Meshinchi S, Walter RB. 2015. High expression of myocyte enhancer factor $2 \mathrm{C}(\mathrm{MEF} 2 \mathrm{C})$ is associated with adverse-risk features and poor outcome in pediatric acute myeloid leukemia: a report from the Children's Oncology Group. Journal of Hematology \& Oncology 8:115 DOI 10.1186/s13045-015-0215-4.

Lopez-Millan B, Sanchez-Martinez D, Roca-Ho H, Gutierrez-Aguera F, Molina O, Diaz de la Guardia R, Torres-Ruiz R, Fuster JL, Ballerini P, Suessbier U, Nombela-Arrieta C, Bueno C, Menendez P. 2019. NG2 antigen is a therapeutic target for MLL-rearranged B-cell acute lymphoblastic leukemia. Leukemia 33:1557-1569 DOI 10.1038/s41375-018-0353-0.

Mak AB, Nixon AM, Moffat J. 2012. The mixed lineage leukemia (MLL) fusion-associated gene AF4 promotes CD133 transcription. Cancer Research 72:1929-1934 DOI 10.1158/00085472.CAN-11-3589.

Meyer C, Burmeister T, Groger D, Tsaur G, Fechina L, Renneville A, Sutton R, Venn NC, Emerenciano M, Pombo-de-Oliveira MS, Barbieri Blunck C, Almeida Lopes B, Zuna J, Trka J, Ballerini P, Lapillonne H, De Braekeleer M, Cazzaniga G, Corral Abascal L, van der Velden VHJ, Delabesse E, Park TS, Oh SH, Silva MLM, Lund-Aho T, Juvonen V, Moore AS, Heidenreich O, Vormoor J, Zerkalenkova E, Olshanskaya Y, Bueno C, Menendez P, TeiglerSchlegel A, Zur Stadt U, Lentes J, Gohring G, Kustanovich A, Aleinikova O, Schafer BW, Kubetzko S, Madsen HO, Gruhn B, Duarte X, Gameiro P, Lippert E, Bidet A, Cayuela JM, 
466 Clappier E, Alonso CN, Zwaan CM, van den Heuvel-Eibrink MM, Izraeli S, Trakhtenbrot L, 467 Archer P, Hancock J, Moricke A, Alten J, Schrappe M, Stanulla M, Strehl S, Attarbaschi A, 468 Dworzak M, Haas OA, Panzer-Grumayer R, Sedek L, Szczepanski T, Caye A, Suarez L, Cave 469 H, Marschalek R. 2018. The MLL recombinome of acute leukemias in 2017. Leukemia 32:273470284 DOI 10.1038/leu.2017.213.

471

472

473

474

475

476

477

478

479

480

481

482

483

484

485

486

487

488

489

490

491

492

493

494

495

496

497

498

499

500

501

502

503

504

505

Meyer C, Hofmann J, Burmeister T, Groger D, Park TS, Emerenciano M, Pombo de Oliveira M, Renneville A, Villarese P, Macintyre E, Cave H, Clappier E, Mass-Malo K, Zuna J, Trka J, De Braekeleer E, De Braekeleer M, Oh SH, Tsaur G, Fechina L, van der Velden VH, van Dongen JJ, Delabesse E, Binato R, Silva ML, Kustanovich A, Aleinikova O, Harris MH, Lund-Aho T, Juvonen V, Heidenreich O, Vormoor J, Choi WW, Jarosova M, Kolenova A, Bueno C, Menendez P, Wehner S, Eckert C, Talmant P, Tondeur S, Lippert E, Launay E, Henry C, Ballerini P, Lapillone H, Callanan MB, Cayuela JM, Herbaux C, Cazzaniga G, Kakadiya PM, Bohlander S, Ahlmann M, Choi JR, Gameiro P, Lee DS, Krauter J, Cornillet-Lefebvre P, Te Kronnie G, Schafer BW, Kubetzko S, Alonso CN, zur Stadt U, Sutton R, Venn NC, Izraeli S, Trakhtenbrot L, Madsen HO, Archer P, Hancock J, Cerveira N, Teixeira MR, Lo Nigro L, Moricke A, Stanulla M, Schrappe M, Sedek L, Szczepanski T, Zwaan CM, Coenen EA, van den Heuvel-Eibrink MM, Strehl S, Dworzak M, Panzer-Grumayer R, Dingermann T, Klingebiel T, Marschalek R. 2013. The MLL recombinome of acute leukemias in 2013. Leukemia 27:21652176 DOI 10.1038/leu.2013.135.

Mohan M, Lin C, Guest E, Shilatifard A. 2010. Licensed to elongate: a molecular mechanism for MLL-based leukaemogenesis. Nature Reviews Cancer 10:721-728 DOI 10.1038/nrc2915.

Mosse YP, Fox E, Teachey DT, Reid JM, Safgren SL, Carol H, Lock RB, Houghton PJ, Smith MA, Hall D, Barkauskas DA, Krailo M, Voss SD, Berg SL, Blaney SM, Weigel BJ. 2019. A Phase II Study of Alisertib in Children with Recurrent/Refractory Solid Tumors or Leukemia: Children's Oncology Group Phase I and Pilot Consortium (ADVL0921). Clinical Cancer Research 25:3229-3238 DOI 10.1158/1078-0432.CCR-18-2675.

Mukai S, Oue N, Oshima T, Imai T, Sekino Y, Honma R, Sakamoto N, Sentani K, Kuniyasu H, Egi H, Tanabe K, Yoshida K, Ohdan H, Yasui W. 2017. Overexpression of PCDHB9 promotes peritoneal metastasis and correlates with poor prognosis in patients with gastric cancer. Journal of Pathology 243:100-110 DOI 10.1002/path.4931.

Nagayama J, Tomizawa D, Koh K, Nagatoshi Y, Hotta N, Kishimoto T, Takahashi Y, Kuno T, Sugita K, Sato T, Kato K, Ogawa A, Nakahata T, Mizutani S, Horibe K, Ishii E, Japan Infant Leukemia Study G. 2006. Infants with acute lymphoblastic leukemia and a germline MLL gene are highly curable with use of chemotherapy alone: results from the Japan Infant Leukemia Study Group. Blood 107:4663-4665 DOI 10.1182/blood-2005-11-4728.

Peer] reviewing PDF | (2019:04:36669:1:1:NEW 13 Jul 2019) 
506

507

508

509

510

511

512

513

514

515

516

517

518

519

520

521

522

523

524

525

526

527

528

529

530

531

532

533

534

535

536

537

538

539

540

541

542

543

544 Smith FO, Rauch C, Williams DE, March CJ, Arthur D, Hilden J, Lampkin BC, Buckley JD, 545

Ogawa R, Streiff MB, Bugayenko A, Kato GJ. 2002. Inhibition of PDE4 phosphodiesterase activity induces growth suppression, apoptosis, glucocorticoid sensitivity, p53, and p21(WAF1/CIP1) proteins in human acute lymphoblastic leukemia cells. Blood 99:3390-3397 DOI 10.1182/blood.v99.9.3390.

Pieters R, Schrappe M, De Lorenzo P, Hann I, De Rossi G, Felice M, Hovi L, LeBlanc T, Szczepanski T, Ferster A, Janka G, Rubnitz J, Silverman L, Stary J, Campbell M, Li CK, Mann G, Suppiah R, Biondi A, Vora A, Valsecchi MG. 2007. A treatment protocol for infants younger than 1 year with acute lymphoblastic leukaemia (Interfant-99): an observational study and a multicentre randomised trial. Lancet 370:240-250 DOI 10.1016/S0140-6736(07)61126-X.

Ritchie ME, Phipson B, Wu D, Hu Y, Law CW, Shi W, Smyth GK. 2015. limma powers differential expression analyses for RNA-sequencing and microarray studies. Nucleic Acids Research 43:e47 DOI 10.1093/nar/gkv007.

Rosales-Avina JA, Torres-Flores J, Aguilar-Lemarroy A, Gurrola-Diaz C, Hernandez-Flores G, Ortiz-Lazareno PC, Lerma-Diaz JM, de Celis R, Gonzalez-Ramella O, Barrera-Chaires E, Bravo-Cuellar A, Jave-Suarez LF. 2011. MEIS1, PREP1, and PBX4 are differentially expressed in acute lymphoblastic leukemia: association of MEIS1 expression with higher proliferation and chemotherapy resistance. Journal of Experimental \& Clinical Cancer Research 30:112 DOI 10.1186/1756-9966-30-112.

Schreiner S, Birke M, Garcia-Cuellar MP, Zilles O, Greil J, Slany RK. 2001. MLL-ENL causes a reversible and myc-dependent block of myelomonocytic cell differentiation. Cancer Research 61:6480-6486.

Schultz KR, Carroll A, Heerema NA, Bowman WP, Aledo A, Slayton WB, Sather H, Devidas M, Zheng HW, Davies SM, Gaynon PS, Trigg M, Rutledge R, Jorstad D, Winick N, Borowitz MJ, Hunger SP, Carroll WL, Camitta B, Children's Oncology G. 2014. Long-term follow-up of imatinib in pediatric Philadelphia chromosome-positive acute lymphoblastic leukemia:

Children's Oncology Group study AALL0031. Leukemia 28:1467-1471 DOI 10.1038/leu.2014.30.

Shannon P, Markiel A, Ozier O, Baliga NS, Wang JT, Ramage D, Amin N, Schwikowski B, Ideker T. 2003. Cytoscape: a software environment for integrated models of biomolecular interaction networks. Genome Research 13:2498-2504 DOI 10.1101/gr.1239303. Buckley CV, Woods WG, Dinndorf PA, Sorensen P, Kersey J, Hammond D, Bernstein ID. 1996. 
546 The human homologue of rat NG2, a chondroitin sulfate proteoglycan, is not expressed on the 547 cell surface of normal hematopoietic cells but is expressed by acute myeloid leukemia blasts

548 from poor-prognosis patients with abnormalities of chromosome band 11q23. Blood 87:11235491133.

550

551

Stam RW. 2013. The ongoing conundrum of MLL-AF4 driven leukemogenesis. Blood

552 121:3780-3781 DOI 10.1182/blood-2013-03-491738.

553

554

Teuffel O, Kuster SP, Hunger SP, Conter V, Hitzler J, Ethier MC, Shah PS, Beyene J, Sung L.

555 2011. Dexamethasone versus prednisone for induction therapy in childhood acute lymphoblastic

556 leukemia: a systematic review and meta-analysis. Leukemia 25:1232-1238 DOI

557 10.1038/leu.2011.84.

558

559

Tomizawa D, Koh K, Sato T, Kinukawa N, Morimoto A, Isoyama K, Kosaka Y, Oda T, Oda M, 560 Hayashi Y, Eguchi M, Horibe K, Nakahata T, Mizutani S, Ishii E. 2007. Outcome of risk-based

561 therapy for infant acute lymphoblastic leukemia with or without an MLL gene rearrangement,

562 with emphasis on late effects: a final report of two consecutive studies, MLL96 and MLL98, of

563

564

565 Trowbridge IS, Thomas ML. 1994. CD45: an emerging role as a protein tyrosine phosphatase

566 required for lymphocyte activation and development. Annual Review of Immunology 12:85-116

567 DOI 10.1146/annurev.iy.12.040194.000505.

568

569

570

Tsutsumi S, Taketani T, Nishimura K, Ge X, Taki T, Sugita K, Ishii E, Hanada R, Ohki M, Aburatani H, Hayashi Y. 2003. Two distinct gene expression signatures in pediatric acute

571

572

573 lymphoblastic leukemia with MLL rearrangements. Cancer Research 63:4882-4887.

van der Linden MH, Valsecchi MG, De Lorenzo P, Moricke A, Janka G, Leblanc TM, Felice M, 574 Biondi A, Campbell M, Hann I, Rubnitz JE, Stary J, Szczepanski T, Vora A, Ferster A, Hovi L, 575 Silverman LB, Pieters R. 2009. Outcome of congenital acute lymphoblastic leukemia treated on

576

577

578 Vitali C, Bassani C, Chiodoni C, Fellini E, Guarnotta C, Miotti S, Sangaletti S, Fuligni F, De

579 Cecco L, Piccaluga PP, Colombo MP, Tripodo C. 2015. SOCS2 Controls Proliferation and

580 Stemness of Hematopoietic Cells under Stress Conditions and Its Deregulation Marks

581 Unfavorable Acute Leukemias. Cancer Research 75:2387-2399 DOI 10.1158/0008-5472.CAN$582 \quad 14-3625$.

583

584 von Mering C, Huynen M, Jaeggi D, Schmidt S, Bork P, Snel B. 2003. STRING: a database of 585 predicted functional associations between proteins. Nucleic Acids Research 31:258-261. 
586

587

588

589

590

591

592

593

594

595

596

597

598

599

600

601

602

603

604

605

606

607

608

609

610

611

612

613

614

615

616

617

618

619

620

621

622

623

624

625

Wang QF, Wu G, Mi S, He F, Wu J, Dong J, Luo RT, Mattison R, Kaberlein JJ, Prabhakar S, Ji H, Thirman MJ. 2011. MLL fusion proteins preferentially regulate a subset of wild-type MLL target genes in the leukemic genome. Blood 117:6895-6905 DOI 10.1182/blood-2010-12324699.

Weng J, Xiao J, Mi Y, Fang X, Sun Y, Li S, Qin Z, Li X, Liu T, Zhao S, Zhou L, Wen Y. 2018. PCDHGA9 acts as a tumor suppressor to induce tumor cell apoptosis and autophagy and inhibit the EMT process in human gastric cancer. Cell Death \& Disease 9:27 DOI 10.1038/s41419-0170189-y.

Wuchter C, Harbott J, Schoch C, Schnittger S, Borkhardt A, Karawajew L, Ratei R, Ruppert V, Haferlach T, Creutzig U, Dorken B, Ludwig WD. 2000. Detection of acute leukemia cells with mixed lineage leukemia (MLL) gene rearrangements by flow cytometry using monoclonal antibody 7.1. Leukemia 14:1232-1238.

Wu Z, Eguchi-Ishimae M, Yagi C, Iwabuki H, Gao W, Tauchi H, Inukai T, Sugita K, Ishii E, Eguchi M. 2015. HMGA2 as a potential molecular target in KMT2A-AFF1-positive infant acute lymphoblastic leukaemia. British Journal of Haematology 171:818-829 DOI 10.1111/bjh.13763.

Yan Y, Zuo X, Wei D. 2015. Concise Review: Emerging Role of CD44 in Cancer Stem Cells: A Promising Biomarker and Therapeutic Target. Stem Cells Translational Medicine 4:1033-1043 DOI 10.5966/sctm.2015-0048.

Zhang X, Takata K, Cui W, Miyata-Takata T, Sato Y, Noujima-Harada M, Yoshino T. 2016. Protocadherin gamma A3 is expressed in follicular lymphoma irrespective of BCL2 status and is associated with tumor cell growth. Molecular Medicine Reports 14:4622-4628 DOI 10.3892/mmr.2016.5808.

Zhou X, Updegraff BL, Guo Y, Peyton M, Girard L, Larsen JE, Xie XJ, Zhou Y, Hwang TH, Xie Y, Rodriguez-Canales J, Villalobos P, Behrens C, Wistuba, II, Minna JD, O'Donnell KA. 2017. PROTOCADHERIN 7 Acts through SET and PP2A to Potentiate MAPK Signaling by EGFR and KRAS during Lung Tumorigenesis. Cancer Research 77:187-197 DOI 10.1158/00085472.CAN-16-1267-T.

Zuber J, Rappaport AR, Luo W, Wang E, Chen C, Vaseva AV, Shi J, Weissmueller S, Fellmann C, Taylor MJ, Weissenboeck M, Graeber TG, Kogan SC, Vakoc CR, Lowe SW. 2011. An integrated approach to dissecting oncogene addiction implicates a Myb-coordinated self-renewal program as essential for leukemia maintenance. Genes \& Development 25:1628-1640 DOI $10.1101 /$ gad.17269211.

Peer) reviewing PDF | (2019:04:36669:1:1:NEW 13 Jul 2019) 
Figure 1

Heat map of the top 20 up-regulated and down-regulated DEGs.

DEGs were identified between MLL-R $(n=139)$ and non-MLL-R $(n=31)$ infant ALL samples by the cutoff $\mid \log 2$ fold change $(F C) \mid>1$ and $P$ value $<0.01$. Each row represents a single gene, each column represents a sample. The gradual color change from green to magenta represents the gene expression values change from low to high. DEG: differentially expressed genes; MLL-R: Mixed Lineage Leukemia rearrangement. 


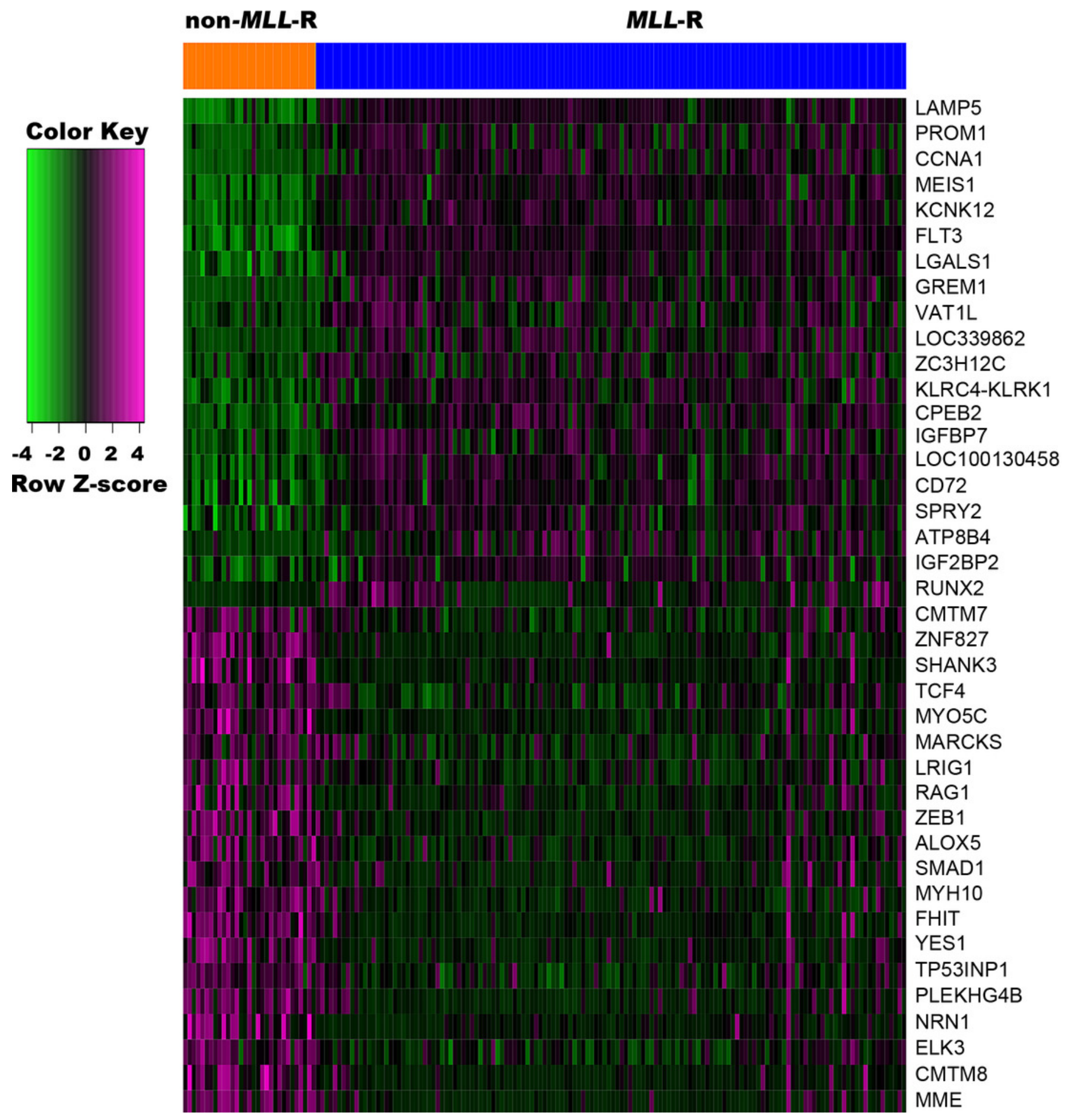


Figure 2

GO-BP function annotation the DEGs

The up-regulated DEGs were enriched in $62 \mathrm{BP}$, terms, and down-regulated DEGs were enriched in 34 BP terms with a cut-off criterion of count $\geq 2$ and $\mathrm{P}$ value $<0.1$. The gradual color change from green to magenta represents the -log10(P Value) change from low to high, the size of point represents the the count of genes. (A) The top 5 significantly enriched GO-BP terms for up-regulated DEGs. (B) The top 5 significantly enriched GO-BP terms for downregulated DEGs. DEG: differentially expressed genes; GO: gene ontology; BP: biological process.
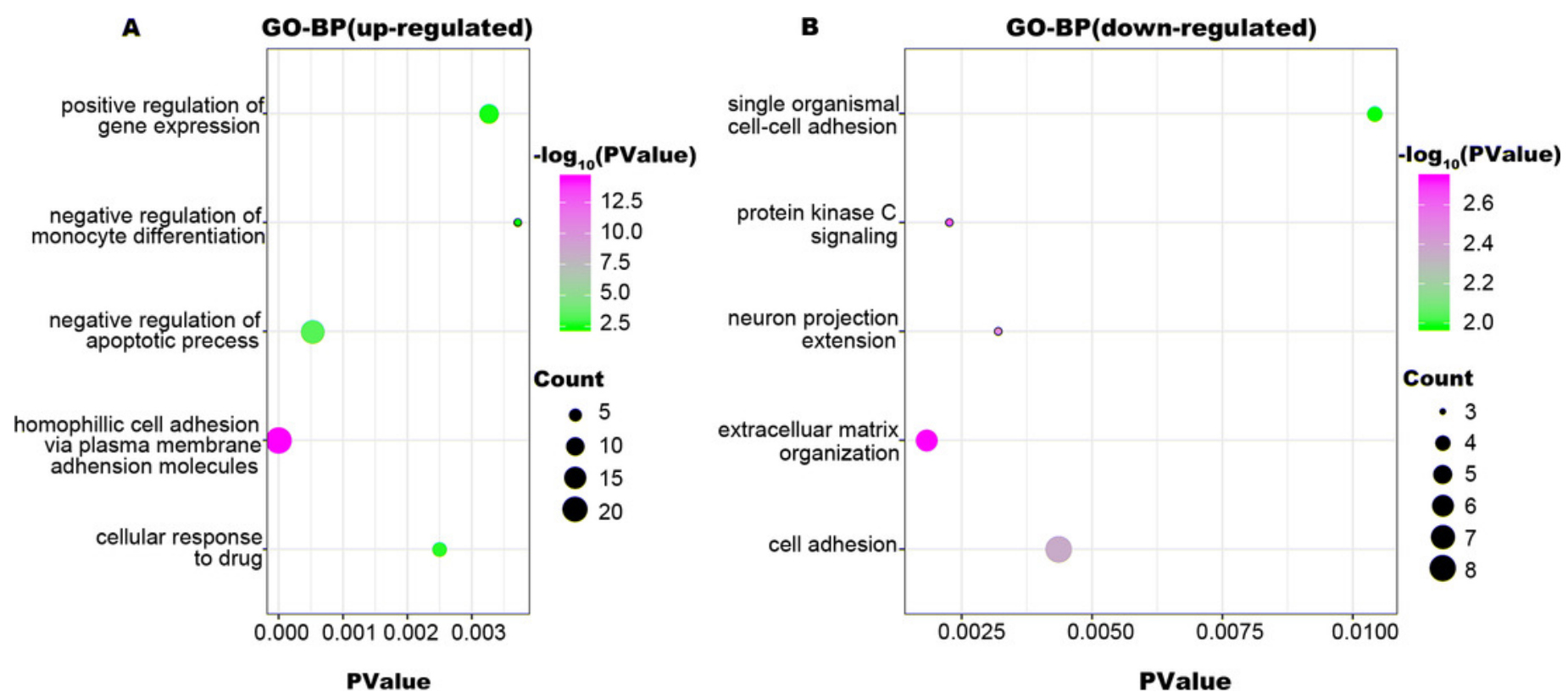
Figure 3

GO-CC function annotation the DEGs

The up-regulated DEGs were enriched in 21 CC terms, and down-regulated DEGs were enriched in $22 \mathrm{CC}$ terms with a cut-off criterion of count $\geq 2$ and $\mathrm{P}$ value $<0.1$. The gradual color change from green to magenta represents the -log10(P Value) change from low to high, the size of point represents the the count of genes. (A) The top 5 significantly enriched GOCC terms for up-regulated DEGs. (B) The top 5 significantly enriched GO-CC terms for downregulated DEGs. DEG: differentially expressed genes; GO: gene ontology; CC: cellular component.
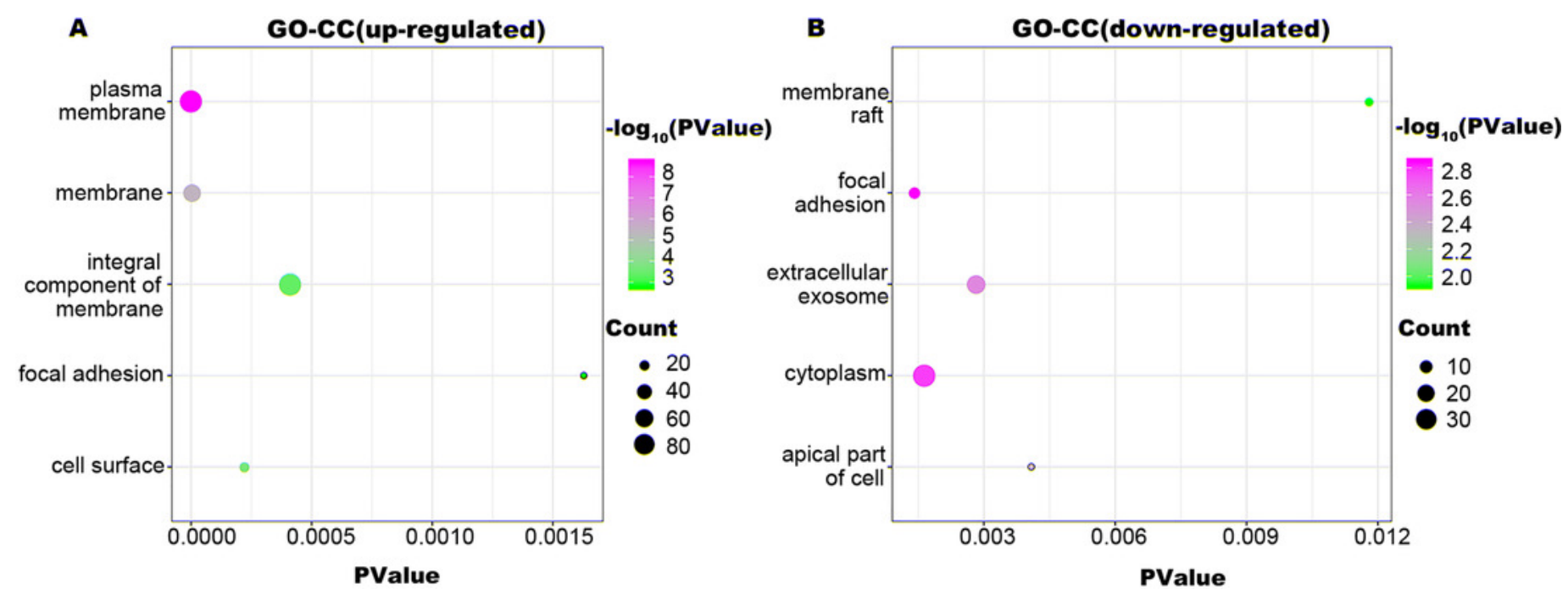
Figure 4

GO-MF function annotation the DEGs

The up-regulated DEGs were enriched in $22 \mathrm{MF}$ terms, and down-regulated DEGs were enriched in 17 MF terms with a cut-off criterion of count $\geq 2$ and $P$ value $<0.1$. The gradual color change from green to magenta represents the -log10(PValue) change from low to high, the size of point represents the the count of genes. (A) The top 5 significantly enriched GOMF terms for up-regulated DEGs. (B) The top 5 significantly enriched GO-MF terms for downregulated DEGs. DEG: differentially expressed genes; GO: gene ontology; MF: molecular function.
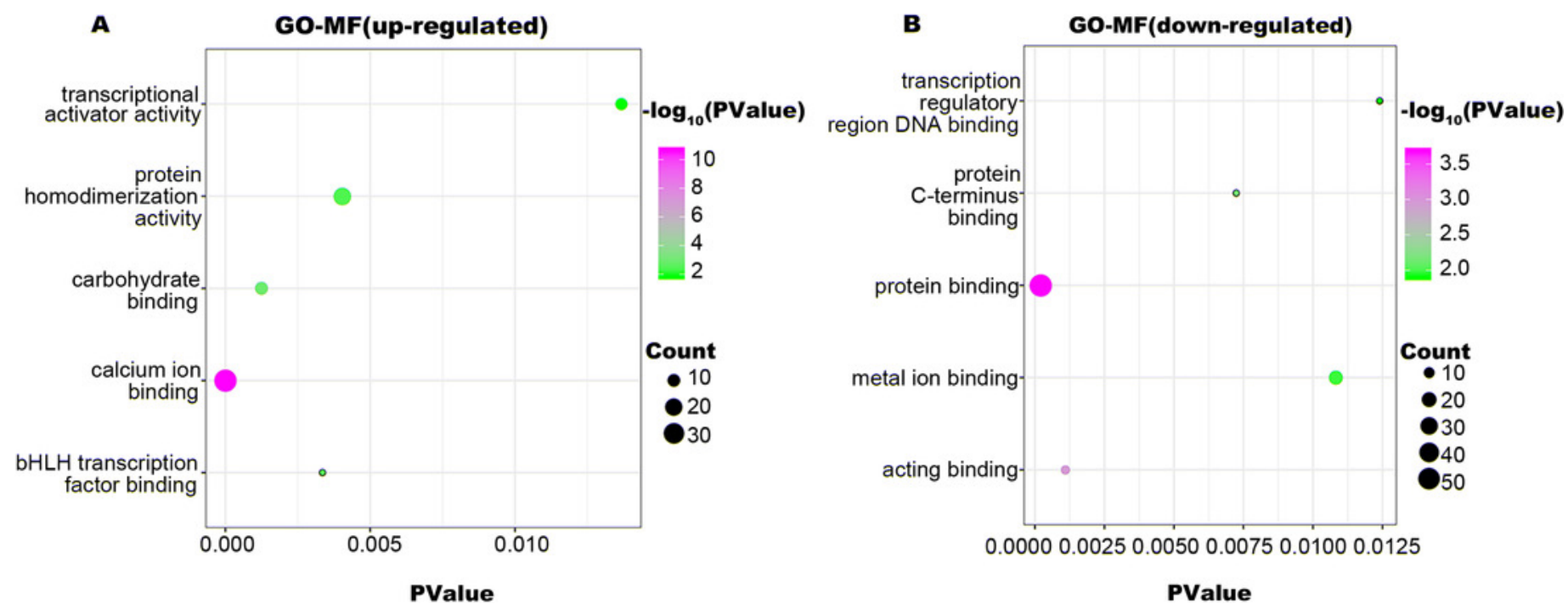


\section{Figure 5}

\section{PPI network of DEGs}

The PPI network of DEGs included 297 nodes and 410 edges with minimum required interaction score $>0.4$ (median confidence). The size of edges change from small to large represents the combined score of nodes change from low to high, the size of nodes represents the count. Red nodes represent up-regulated genes, yellow nodes represent down-regulated genes. PPI: protein - protein interaction; DEG: differentially expressed genes. 


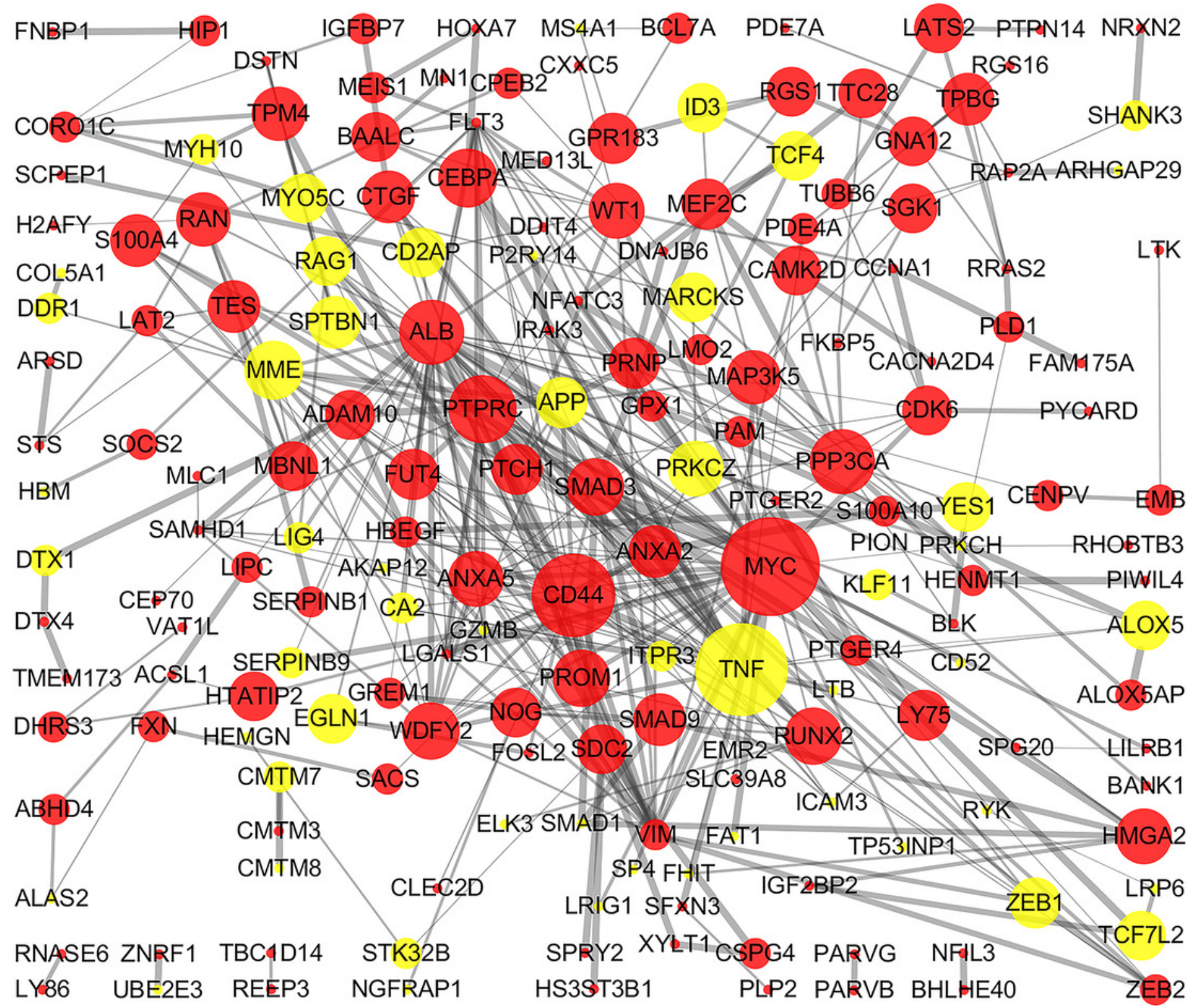




\section{Figure 6}

Bio-functional module of DEGs

The bio-functional module with the maximal MCODE score contained 11 up-regulated and four down-regulated DEGs. The size of edges change from small to large represents the combined score of nodes change from low to high, the size of nodes represents the count. Red nodes represent up-regulated genes, yellow nodes represent down-regulated genes. DEG: differentially expressed genes; MCODE: Molecular COmplex Detection.

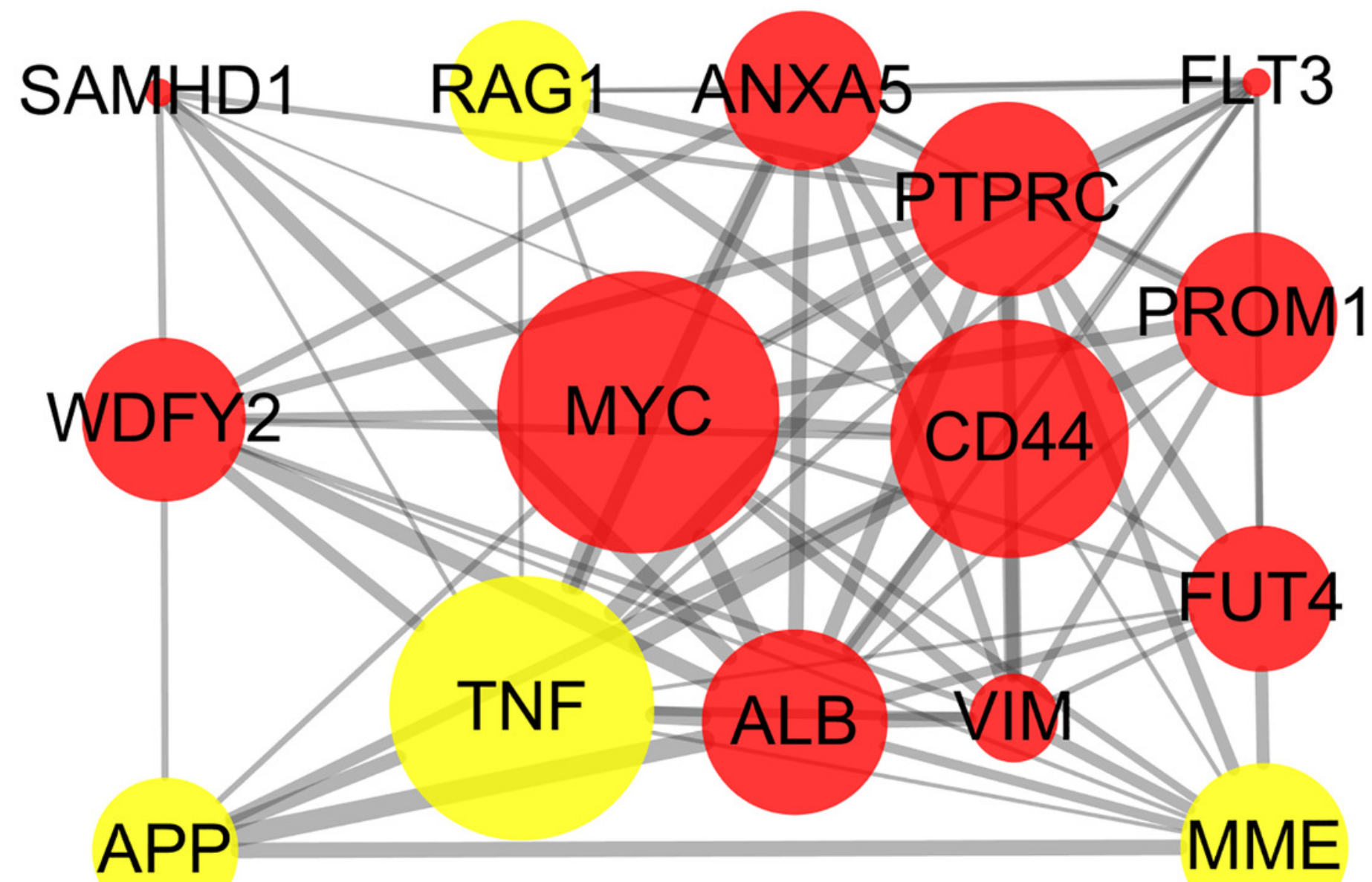




\section{Figure 7}

Drug-gene interactions

Drug-gene interactions. 23 drug-gene interactions including 4 up-regulated hub genes and 24 drugs were identified by DGIdb. Red nodes represent up-regulated hub genes and green nodes represent the drugs. DGIdb: Drug-Gene Interaction database.

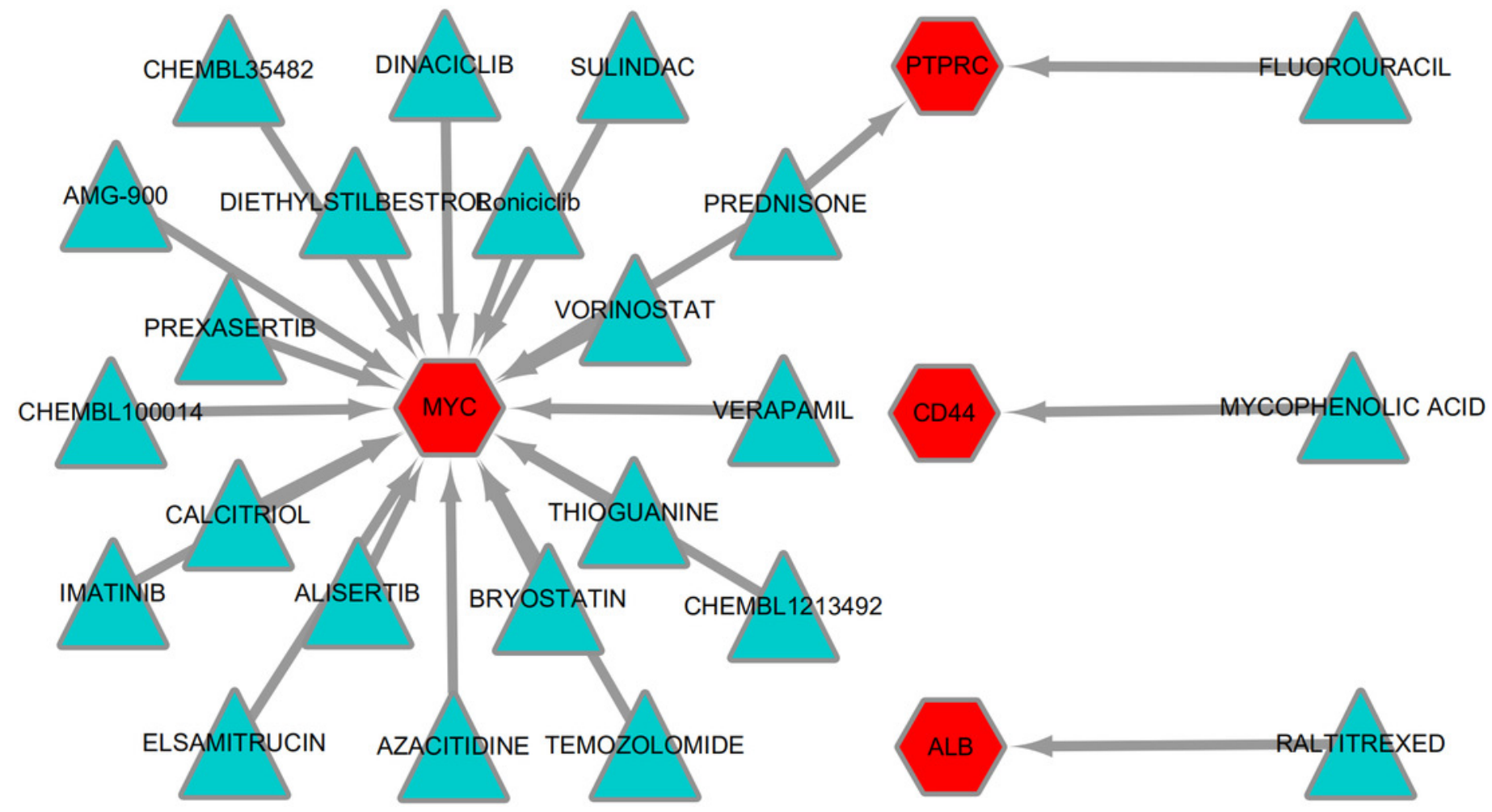




\section{Table $\mathbf{1}$ (on next page)}

KEGG pathways of DEGs

KEGG: Kyoto encyclopedia of genes and genomes; DEG: differentially expressed genes 


\begin{tabular}{|c|c|c|c|}
\hline Term & Genes & Type of DEGs & PValue \\
\hline Transcriptional misregulation & $\begin{array}{l}\text { MEF2C, PROM1, CEBPA, LMO2, FLT3, RUNX1, HM } \\
\text { RUNX2, MEIS1, MYC, WT1 }\end{array}$ & , up-regulated & 0.000 \\
\hline Acute myeloid leukemia & CEBPA, FLT3, RUNX1, MYC & up-regulated & 0.042 \\
\hline Oxytocin signaling pathway & $\begin{array}{l}\text { MEF2C, CAMK2D, GUCY1A3, PPP3CA, NFA } \\
\text { CACNA2D4 }\end{array}$ & , up-regulated & 0.056 \\
\hline Proteoglycans in cancer & CD44, RRAS2, CAMK2D, HBEGF, PTCH1, MYC, SDC2 & up-regulated & 0.058 \\
\hline Renin secretion & PTGER2, PTGER4, GUCY1A3, PPP3CA & up-regulated & 0.058 \\
\hline MAPK signaling pathway & $\begin{array}{l}\text { MEF2C, MAP3K5, RRAS2, GNA12, PPP3CA, NFATC3, } \\
\text { CACNA2D4 }\end{array}$ & , up-regulated & 0.059 \\
\hline Pathways in cancer & $\begin{array}{l}\text { CEBPA, PTGER2, PTGER4, FLT3, GNA12, SMAD3, PTC } \\
\text { CDK6, RUNX1, MYC }\end{array}$ & , up-regulated & 0.092 \\
\hline MicroRNAs in cancer & SPRY2, CD44, VIM, ZEB2, CDK6, HMGA2, MYC, DDIT4 & up-regulated & 0.099 \\
\hline Alzheimer's disease & $A P P, T N F, M M E, I T P R 3$ & \multicolumn{2}{|c|}{ down-regulated 0.053} \\
\hline TGF-beta signaling pathway & $T N F, I D 3, S M A D 1$ & \multicolumn{2}{|c|}{ down-regulated 0.068} \\
\hline Hematopoietic cell lineage & $T N F, M S 4 A 1, M M E$ & \multicolumn{2}{|c|}{ down-regulated 0.072} \\
\hline
\end{tabular}

2 KEGG: Kyoto encyclopedia of genes and genomes; DEG: differentially expressed genes 
Table 2 (on next page)

Top 10 hub genes that evaluated by the methods including MCC (Maximal Clique Centrality), Degree and Betweenness 
1 Table 2 Top 10 hub genes that evaluated by the methods including MCC (Maximal Clique Centrality), Degree 2 and Betweenness

3

4

5

6

7

8

9

\begin{tabular}{llllll}
\hline Gene & MCC Score & Gene & Degree Score & Gene & Betweenness Score \\
\hline MYC & 22218 & MYC & 43 & ALB & 8542.027612 \\
CD44 & 22075 & ALB & 42 & MYC & 8398.777703 \\
ALB & 21713 & TNF & 33 & TNF & 4702.068242 \\
PTPRC & 21310 & CD44 & 26 & CD44 & 4164.511092 \\
TNF & 19364 & PTPRC & 22 & PPP3CA & 2262.216619 \\
VIM & 16980 & VIM & 20 & SDC2 & 2006 \\
WDFY2 & 11570 & SMAD3 & 18 & FLT3 & 1790.958256 \\
MME & 10849 & FLT3 & 17 & MAP3K5 & 1762.347815 \\
ANXA5 & 8334 & ANXA5 & 15 & SMAD3 & 1738.446661 \\
FUT4 & 7200 & MME & 14 & PTPRC & 1709.765874 \\
\hline
\end{tabular}

